\title{
Ecology: Its relative importance and absolute irrelevance for a Christian: A Kierkegaardian transversal space for the controversy on eco-theology
}

\begin{tabular}{|c|c|}
\hline \multicolumn{2}{|c|}{$\begin{array}{l}\text { Author: } \\
\text { Hermen Kroesbergen }\end{array}$} \\
\hline \multicolumn{2}{|c|}{$\begin{array}{l}\text { Affiliations: } \\
{ }^{1} \text { Justo Mwale Theological } \\
\text { University College, Lusaka, } \\
\text { Zambia }\end{array}$} \\
\hline \multicolumn{2}{|c|}{$\begin{array}{l}{ }^{2} \text { Department of Dogmatics } \\
\text { and Christian Ethics, Faculty } \\
\text { of Theology, University of } \\
\text { Pretoria, South Africa }\end{array}$} \\
\hline \multicolumn{2}{|c|}{$\begin{array}{l}\text { Note: } \\
\text { Dr Hermen Kroesbergen is a } \\
\text { postdoctoral fellow of Prof. } \\
\text { Dr Johan Buitendag in the } \\
\text { Department of Dogmatics } \\
\text { and Christian Ethics, Faculty } \\
\text { of Theology, University of } \\
\text { Pretoria, South Africa. }\end{array}$} \\
\hline \multicolumn{2}{|c|}{$\begin{array}{l}\text { Correspondence to: } \\
\text { Hermen Kroesbergen }\end{array}$} \\
\hline \multicolumn{2}{|c|}{$\begin{array}{l}\text { Email: } \\
\text { hermen.kroesbergen@gmail. } \\
\text { com }\end{array}$} \\
\hline \multicolumn{2}{|c|}{$\begin{array}{l}\text { Postal address: } \\
\text { Private Bag X20, Hatfield } \\
0028 \text {, Pretoria, South Africa }\end{array}$} \\
\hline \multicolumn{2}{|c|}{$\begin{array}{l}\text { Dates: } \\
\text { Received: } 08 \text { May } 2014 \\
\text { Accepted: } 17 \text { June } 2014 \\
\text { Published: } 10 \text { Nov. } 2014\end{array}$} \\
\hline \multicolumn{2}{|c|}{$\begin{array}{l}\text { How to cite this article: } \\
\text { Kroesbergen, H., 2014, } \\
\text { 'Ecology: Its relative } \\
\text { importance and absolute } \\
\text { irrelevance for a Christian: A } \\
\text { Kierkegaardian transversal } \\
\text { space for the controversy } \\
\text { on eco-theology', HTS } \\
\text { Teologiese Studies/ } \\
\text { Theological Studies 70(1), } \\
\text { Art. \#2719, } 8 \text { pages. http:// } \\
\text { dx.doi.org/10.4102/hts. } \\
\text { v70i1.2719 }\end{array}$} \\
\hline \multicolumn{2}{|l|}{ Read online: } \\
\hline 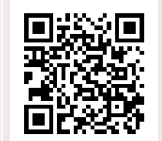 & $\begin{array}{l}\text { Scan this QR } \\
\text { code with your } \\
\text { smart phone or } \\
\text { mobile device } \\
\text { to read online. }\end{array}$ \\
\hline
\end{tabular}

The controversy about the importance of eco-theology or creation spirituality seems to be in a deadlock. Those who support it and those who oppose it do not even seem to be able to communicate with one another. On the one hand, Celia Deane-Drummond, for example, writes in her Eco-theology (2008:x): 'I find it astonishing that courses on eco-theology do not exist in many university departments of theology and religious studies.' Matthew Fox desperately asks in his Creation spirituality (1991:xii): 'Need I list the [environmental] issues of our day that go virtually unattended to in our culture?' On the other hand, evangelical Christians are known for their ecological 'blind spot' (Davis 2000), until recently at least. Pentecostal proponents of the prosperity gospel preach a consumer-lifestyle for all Christians, which is not very eco-friendly (cf. Kroesbergen 2013). Even in more mainline Christianity we find, for example, the well-known theologian Robert Jenson who writes in his Systematic theology: Volume 2 (1999:113, n. 2): 'Recent waves of "creation spirituality" are simply apostasy to paganism. And it is such unguarded, even unargued judgement that is required of the church.' We find ecotheologians, who do not understand that not everyone agrees with them on the one hand, and opposing theologians, who do not even feel the need to argue against them on the other hand. What would be needed to re-open communication between those in favour of eco-theology or creation spirituality, and those opposed to it?

\section{Introduction}

This article argues that the current miscommunication regarding eco-theology or creation spirituality can be clarified using Kierkegaardian concepts like 'teleological suspension' and 'qualitative difference' in a kind of transversal space. The Kierkegaardian concepts will be discussed further on in this article, but let us first elaborate a bit on what is meant by a 'transversal space'. Transversal space is a concept that the well-known theologian Wentzel van Huyssteen (1999, 2006) borrowed from philosopher Calvin Schrag (cf. 1992:9) to illustrate the relationship between theology and the sciences in our postfoundationalist era. Transversal space is originally a mathematical term to describe the intersection of different lines or surfaces. Van Huyssteen (1999) uses it to emphasise the many intersections or overlaps in reasoning strategies that are used by different epistemic communities such as science and theology. Even more helpful than the mathematical background of the metaphor, I find the quasi-etymological background that Van Huyssteen hints at in a more recent work (2006:18): '[T] he important postfoundationalist notion of transversality replaces modernist, static notions of universality.' We should neither look for universal ground to communicate between different fields such as theology and the sciences, nor give up communication in a post-modernist fashion, but transversally we should look for points of contact between different concrete, contextual practices. Such a transversal space is needed to get the two sides in the debate on eco-theology to communicate.

If we use Kierkegaardian concepts to fill in this transversal space, however, as I will propose, this will require adjustments of our expectations of transversal spaces. Van Huyssteen (2006:16) states that within transversal spaces we identify overlaps and similarities, but differences as well. It is nonetheless questionable how deep he allows these differences to be. He (2006:17) opposes the idea of 'a radical difference between scientific and theological rationality'. He (2006:9) states that 'specific divisive issues [...] need to be discussed', but he (2006:34) envisages the result as being that 'traditional epistemic boundaries and disciplinary distinctions are blurred'. I think he is jumping the gun here; in a genuine discussion we do not know the result in advance. Maybe through discussion within a transversal space boundaries and differences will be reinforced with vengeance. Apart from suggesting openings for communication between those in favour of eco-theology or

Copyright: (๑) 2014. The Authors. Licensee: AOSIS OpenJournals. This work is licensed under the Creative Commons Attribution License. 
creation spirituality, and those opposed to it, this article will also hint at limits to the hopes of what transversal or similar postfoundationalist discussions could accomplish. These hopes are expressed by Van Huyssteen and his colleague Johan Buitendag, who argues that 'whereSystematic Theology calls for the intrinsic coherence of theology, a Christian theology of nature extends such a coherency to an appreciation of theology and of the intellectual world as a whole' (2009), and dreams of a 'ontluikende gemeenskap en geheelskap' (2013) relating science and theology.

To open up a transversal space between the two sides in the debate on eco-theology, both sides need to look beyond the boundaries of their own discourse. In the next section, I will start with what would enable the eco-theologians to do so.

\section{Suspending judgement}

The rise of eco-theology and creation theology is part of a remarkable larger trend in society. As Deane-Drummond (2008) starts her book Eco-theology:

Contemporary concern for the environment, broadly understood as a turn to ecology, takes its bearings from secular concerns about the environment that have developed and intensified over the last few decades. (p. ix)

In only a few decades there has been a major shift in public opinion. After the Second World War an industrial revolution took place in the food production, factory farming was introduced, and all people were concerned about was people. In 1947 the British Minister of Agriculture could introduce a new Act on Agriculture without any reference to the well-being of animals or environment:

$[T] \mathrm{o}$ promote a healthy and efficient agriculture capable of producing that part of the nation's food which is required from home sources at the lowest price consistent with the provision of adequate remuneration and decent living conditions for farmers and workers, with a reasonable return on capital invested. (n.p.)

In 2006 the Partij voor de Dieren entered the Dutch parliament fighting mainly for animal rights and animal welfare. They argue for a compassionate treatment of animals, referring to Gandhi's statement: 'The greatness of a nation and its moral progress, can be judged by the way its animals are treated' (quoted in MacKinnon 2007:320), and can count on international support; for example, the South African author J.M. Coetzee attempted to be a candidate for the Partijuoor de Dieren.

Within a period of 60 years the attitude towards animals and the environment in general have shifted drastically. With respect to such a drastic change in the 18th century in the way people are punished, Michel Foucault ([1975] 1977) famously wondered:

$[P]$ erhaps, in its time, it gave rise to too much inflated rhetoric; perhaps it has been attributed too readily and too emphatically to a process of 'humanization', thus dispensing with the need for further analysis. (p. 8)

I want to suggest that this is often the case with respect to ecology as well; the concern for ecology is too readily ascribed to a process of humanisation (cf. the plea to treat animals compassionately) and civilisation. This would explain why Deane-Drummond finds it astonishing that so many colleagues do not share her concern for ecology; she consciously or unconsciously regards them as uncivilised. For a change that happened so quickly, however, it would be better to suspend judgement with respect to civilisation.

On top of that, the importance of eco-theology is often treated as the direct implication of plain factual truths. This can be seen in Fox, who, quoted previously, wonders why so many ecological issues do not get the attention they deserve in his opinion. From a different angle, Van Huyssteen, in his plea for transversal communication also suggests that theology that disregards ecology would be sacrificing truth. He (2006) writes:

I think we can conclude [...] that any intradisciplinary attempt at a theological anthropology, no matter how well intended, will always be incomplete, if not seriously impaired, if the more holistic approach of interdisciplinary theology is not allowed to complement, and contribute to, the issue of defining the human condition. (p. 278)

Now, does this imply that, for example, Jenson's theology is incomplete because Jenson refuses to enter into discussion with eco-theology and ecology? Does this imply Jenson's theology is impaired, and lacks truth?

In 2011 philosopher Kwame Anthony Appiah in The honor code analysed how moral revolutions happen. $\mathrm{He}$ looked at the end of duels, foot-binding and slavery and discovered that appeals to reason or morality were never enough to bring about change. ${ }^{1}$ The arguments had been there for centuries, there is no new truth discovered which brings about a moral revolution. I want to suggest that this holds for the moral revolution in the second half of the 20th century with regards to ecology as well. The difference between 1947 and 2006 cannot be explained by the discovery of new facts. Take, for example, Darwin's discoveries; they are very prominent in the works of many proponents of eco-theology, but previously these discoveries led to the quite different approach of 'Social Darwinism', which was not concerned with ecology in the modern sense at all (cf. Buitendag 2009). The recognition of factual discoveries in itself is not what distinguishes those in favour of ecotheology or creation spirituality, and those opposed to it; therefore it is unreasonable to suggest that those who oppose a theological concern for ecology disregard truth.

In conclusion, to open up a transversal space between the two sides in the debate on eco-theology, it is important for those in favour of eco-theology and creation spirituality, such as Deane-Drummond and Fox quoted at the beginning of this article, to suspend their (implied) judgement of the other side with respect to its civilisation and regard for the truth. Before we outline the tasks for the opponents of eco-theology, let us first analyse their position from a Kierkegaardian point of view.

\section{Qualitative difference}

As mentioned at the outset of this article, there are different strands of opponents to eco-theology. Advocates of the 
prosperity gospel preach consumerist and materialistic values that are hardly compatible with eco-theology. Some evangelicals have lately recognised the importance of ecology (cf. Simmons 2009:41f.), but for long this has not received much attention. In a journal for evangelical theology, John J. Davis (2000:284) analysed 20 major recent evangelical handbooks in theology and found that in almost half of them, ecology is ignored completely, whereas in the others the theme is marginal compared to, for example, the debate on evolution and creationism. Missiologist Chris Sugden (1993) explains this lack of interest out of the importance of matters of the salvation and redemption of human beings in evangelical circles:

Ideas that the trees and the land and the rivers, let alone the foxes and the butterflies are worth the time, attention, and the resources of the Christian constituency have struggled to find acceptance in evangelical counsels. (p. 119)

Sugden suggests here a weighing of the importance of different objectives; personal salvation is more important than ecology. The above previously quoted mainline theologian Jenson (1999) takes this argument one step further and I want to take his statement here as starting point for the analysis of the possible critique of eco-theology:

Recent waves of 'creation spirituality' are simply apostasy to paganism. And it is such unguarded, even unargued judgment that is required of the church. (p. 113, n. 2)

We can identify two separate types of arguments against eco-theology in these two lines. In the first line he interprets creation spirituality as paganism. In line with Sugden's point, this may suggest that according to Jenson, eco-theology pays the kind of attention to nature that should be addressed to God. In this article I will leave this argument aside. ${ }^{1}$ In the second line Jenson seems to go beyond Sugden. Now he is not weighing the relative importance of different causes, but asks for unguarded and even unargued judgement. I want to focus on this kind of argument against eco-theology here. Are the objectives of the church that important that even arguing for them would already be relativising them too much? Is faith so much more important than ecology that even providing reasons for this judgement would be too downgrading?

The provocative nature of Jenson's statement recalls one of his major influences, Karl Barth, who, for example, wrote a work against natural theology entitling it Nein! (1934). Abouta decade before he ([1922] 1968) rewrote his commentary on Romans, attacking all possible positions and systems, however, stating in the new foreword:

If I have a system, it is limited to a recognition of what Kierkegaard called 'the infinite qualitative distinction' between time and eternity, and to my regarding this as possessing negative as well as positive significance: 'God is in heaven, and thou art on earth'. (p. 10)

In what follows I would like to show that Sören Kierkegaard's way of thinking, and especially his concepts of the 'qualitative difference', mentioned by Barth, and

1.For a discussion of how Jenson and others create a false sense of security by the way they present the Christian belief in this respect, see Kroesbergen (2005). 'teleological suspension of the ethical', can open up a transversal space between those in favour of eco-theology or creation spirituality, and those opposed to it.

It is a bit anachronistic to apply Kierkegaard's thoughts to eco-theology, given that this approach only emerged as a response to American historian Lynn White's famous accusation in 1967 that Christianity is responsible for the ecological crisis. Therefore, obviously Kierkegaard himself did not write about eco-theology. Both the sharp distinction between human existence and the natural world in his work and Kierkegaard's reflections on the possible teleological suspension of the ethical, however, justify the application of his thoughts to the debate, or rather, lack of debate, between those in favour of eco-theology or creation spirituality, and those opposed to it. The special place of the human being in nature that Kierkegaard assigns to human beings does support a sharper distinction between human beings and other creatures than often is accounted for in eco-theology. The concern for ecology, environment and global climate change can arguably be regarded as a special instance of the ethical which, according to Kierkegaard, may need to be suspended when matters of redemption and salvation come into play. In Kierkegaard's work, however, we also find strict guidelines for when it is allowed to apply a teleological suspension of the ethical. Using both the concepts of qualitative difference and teleological suspension and the guidelines attached to it, this article intends to set parameters acceptable to both sides to initiate the important but currently non-existent debate between those in favour of eco-theology and those opposed to it.

The qualitative difference is a concept that figures in many of Kierkegaard's works, the teleological suspension of the ethical especially in his Fear and trembling ([1844] [1846] 1994). ${ }^{2}$ In Fear and trembling Kierkegaard discusses a dilemma concerning Abraham and his trial of sacrificing Isaac. Either Abraham is truly the father of faith and expressed his faith by his willingness to sacrifice Isaac, or he should not have been willing to sacrifice his son. Immanuel Kant ([1793] 1960) defended the latter position:

[E]ven though something is represented as commanded by God, through a direct manifestation of Him, yet, if it flatly contradicts morality, it cannot, despite all appearances be of God (for example, were a father ordered to kill his son who is, so far as he knows, perfectly innocent). (p. 81f.)

According to Kierkegaard ([1844] [1846] 1994:225), then Abraham can no longer serve as the father of faith, however, but he would be a murderer and at best 'the discoverer of repentance'. Kierkegaard ([1844] [1846] 1994:225), however, sets out to explain how 'it could occur to the Church to make Abraham the father of faith and the friend of God'. Abraham

2.Fear and trembling was actually written under a pseudonym. There have been many discussions about the meaning and importance of Kierkegaard's pseudonyms. For this article, I interpret Kierkegaard's use of pseudonyms as a way to avoid discussions about his personal faith; if he had written about the nature of true faith under his own name, he might have occasioned discussions as to whether he himself proudly claimed to have true faith, or sinfully admitted that he lacked true faith. By not entering into such discussions I feel justified to treat in this article the pseudonymous works as Kierkegaard's own 
must have had a special licence based on his individual relationship to the eternal God to ignore the universal duty not to kill. Kierkegaard ([1844] [1846] 1994:107) claims that 'either there is a paradox, that the individual as the individual stands in an absolute relation to the absolute/or Abraham is lost'. From Abraham he ([1844] [1846] 1994:70) transfers this argument to faith in general: 'Either there is an absolute duty towards God [...]/or else faith never existed.' Kierkegaard defends the position that if faith exists, and is not just a stage within ethics, it must be qualitatively different from ethics and in extreme cases such as that of Abraham even be justified to suspend someone's ethical duties. Now, before we can argue whether such a qualitative difference that allows one to suspend ethics exists, let us first clarify what is meant by a qualitative difference.

Imagine that you have an appointment at a place you are not familiar with. Someone gave you directions, but when you reach the area, you discover that there are signs to show you the way as well. The directions would have worked, but the signs are a welcome addition. There is no qualitative difference between the two. If we apply this perspective to ecology, one might say that God already urged us to be good stewards of his creation, but that the ecological crisis as an additional sign has given us a wake-up call.

Now contrast this with another example, taken from Kierkegaard's Purity of heart ([1847] 2012) ${ }^{3}$ :

If a man loves a girl for sake of her money, who will call him a lover? He does not love the girl, but the money. He is not a lover, but a money-seeker. But if a man said, 'It is the girl I love and she has money,' and he should ask us for our judgment, [...] then a good answer would be, 'It is a difficult matter with this money. Money may have a great influence, one can easily be deceived, and it is very difficult to know oneself'. (p.29)

This is a very different case from the one before. Signs are a helpful addition to directions to show you the way; here, however, money is not helpful in showing this man the way to his lover, on the contrary. Kierkegaard ([1847] 2012) continues:

If he were really very intent on this matter he could even wish that the money were [sic] not there, just to test his love. For a true lover would say, 'The girl has only one fault, she has money. (p. 29)

The additional reason in this case, namely that the girl has money, threatens to affect the first reason, love.

Money affects the relationship of love, like Kierkegaard ([1844] [1846] 1994) states concerning another example in The book on Adler:

In case a son were [sic] to say, 'I obey my father, not because he is my father, but because he is a genius or because his commands are always profound and clever' - then this filial obedience is affected. (p. 211)

Additional reasons are not always helpful in the way that

3.Some regard what is described in Purity of heart as Kierkegaard's genera religiousness instead of Christianity as described for example in Fear and trembling religiousness instead of Christianity as described for example in Fear and trembling
and Concluding unscientific postscript (cf. Rudd 1993:136f.), but for our purposes and Concluding unscientific postscript (cf. Rudd 1993:136f.), but for our purpc
this example from Purity of heart works fine to illustrate Christianity as well. signs are helpful if you try to find your way to a new place. New reasons may be of such a different nature that they threaten to replace the previous reasons. That the girl in the example has money may not be a matter of providential guidance, but may be a problem, seeing as love is so much unlike money.

The contrast between the example of finding your way to a new place and loving a girl with money shows that a qualitative difference may be present on two levels; on the one hand, there is a qualitative difference between the case of pointing out directions and the case of loving a girl with money, whilst on the other hand, this qualitative difference consists in the fact that within the latter case there is a qualitative difference between the two reasons for pursuing a relationship with this girl: love and money. Given that the latter would lead to the first one by implication, let us focus on the latter qualitative difference; two reasons pointing in the same direction, but not supporting one another, on the contrary.

A realistic or cynical interpretation of the example may be that it does not matter whether money as a reason to remain with the girl takes over for a while; when you find love again later, you will be glad that you stayed although it was for more mundane reasons. But looking back once you have found love again from that perspective of love, would you really be happy about having loved the girl for her money? I would say that that would only be the case if the new perspective is still partly cynical itself, and not the qualitatively different perspective of innocent love. Kierkegaard ([1847] 2012) imagines a pair giving away their money so that it will not impair their love, and says:

Let us hope that no one would set about to disturb the innocent fancy of this beautiful thought by telling us, 'What life will surely teach that pair!' Alas, there is a wretched knowledge. (p. 30)

Kierkegaard ([1847] 2012:30) acknowledges that it is a kind of knowledge, but exclaims that with that kind of knowledge 'one might prefer to learn the art of forgetting'. Here we find yet another level of qualitative difference; that between a cynical and an innocent interpretation of someone who wishes 'that the money were not there, just to test his love' (Kierkegaard [1847] 2012:29). Even if one adopts the cynical interpretation, this would reinforce the qualitative difference between love and money as reason for pursuing a relationship.

This argument proves that qualitative differences exist, nonetheless, whether there is a qualitative difference in the case of the disagreement concerning eco-theology remains an open question. Now, if, for sake of the argument, we apply this perspective to ecology, we may say that God urged us to be good stewards of his creation, and that the ecological crisis and other secular pointers in a similar direction are not helpful additional signs, but that these secular reasons are rather complicating matters, for they may have great influence, one can easily be deceived by following secular reasons instead of God, seeing as it is very difficult to know oneself.

That Kierkegaard ([1844] [1846] 1994) holds this position becomes clear when he states about attempts 'to make 


\section{Christianity plausible':}

$[I] \mathrm{f}$ this were $[s i c]$ to succeed, then would this effort have the ironical fate that precisely upon the day of its triumph it would have lost everything and entirely quashed Christianity. (p. 162)

Ludwig Wittgenstein (2007:58) moved in a similar direction when he called basing Christianity on evidence 'ludicrous', and his pupil Peter Winch (in Springsted 2004) more recently expressed this judgement thus:

What would damage the integrity of such a belief is not so much a demonstration of its historical falsity as the asking of such technical historical questions concerning it in the first place. It is a belief of a sort which precludes the asking of such questions. (p. 368)

Historical arguments are qualitatively different from reasons of faith. Comparing this to the case of loving the girl with money, Kierkegaard, Wittgenstein and Winch might say: 'Christianity has only one fault, scientific arguments support it.' As Kierkegaard ([1848] 1971) asks elsewhere:

Who possesses most? Is it he who possesses God and at the same time much else, or he who being deprived of all else possesses God alone? Surely it is the latter, for all else 'is loss'. (p. 230)

Outside support is not helpful, but rather a loss. If we subsequently apply this to the debate on eco-theology, Jenson cum suis may say: 'The cause of ecology has one fault, secular arguments support it.'

Whether or not one agrees with this discernment concerning Christianity and ecology, whether or not one agrees that the qualitative difference exists here, given the existence of qualitative differences such an argument is possible. If we transversally connect this possibility to those arguing in favour of eco-theology, we see that at least one of their arguments needs to be adjusted. In the previous section we heard Van Huyssteen suggest that theology is incomplete and therefore impaired if it does not take into account secular science concerning ecology. If there is a possible qualitative difference between theological and secular arguments such as there is between love and money, however, then the incompleteness of theology without scientific knowledge may not be impairment, but rather an advantage. Incompleteness at least does not necessarily imply impairment. This may answer Fox's astonishment that so many ecological issues do not get the attention they deserve according to him. Van Huyssteen's (2006:278) claim about impaired theology may be turned upside down: 'All scientific arguments to support Christian causes from evolutionary biology etc., no matter how well intended, no matter how true they may be, may always harm Christianity.'

\section{Teleological suspension of the ethical}

Those arguing against eco-theology such as Jenson may be interpreted as presupposing a qualitative difference between theology and secular arguments for ecology as referred to by eco-theologians. The qualitative difference as such, however, does not yet explain why Jenson claims that it is required of the church to promulgate such a judgement unargued. Why could it even be wrong to argue that there is this qualitative difference? To make this plausible we need Kierkegaard's accompanying concept of teleological suspension of the ethical.

One difference between Kierkegaard's example of Abraham in Fear and trembling and the previously discussed example of loving a girl with money is that the alternative reason in Abraham's case is good and noble in itself. Money is a rather base reason compared to love, whereas Abraham is confronted with his ethical duty to take care of his children. We can adapt the example of loving the girl likewise by imagining the man and the girl have children together. In that case 'staying together for the children's sake' would not be an additional reason to love as in the example of asking directions and following signposts, but just like 'money' 'for the children's sake' is qualitatively different from 'love' as a reason for a relationship. If he loves the girl, the fact that they have to stay together for the children's sake is not an additional supporting reason; it does not add on love as it is within a different category.

This point is made by Kierkegaard when he criticises pastor Adler in The book on Adler [1844] [1846] 1994): Adler first claimed to have a direct revelation from Christ resulting in a certain collection of sermons, later on when he was questioned by the church's authorities, he tried to defend his sermons with philosophical and theological arguments. According to Kierkegaard, if we allow the possibility that Adler genuinely had a revelation, these other arguments do not add anything. Being a genius is something qualitatively different from being an apostle (cf. Kierkegaard [1844] [1846] 1994:190ff.); to the authority bestowed on someone by revelation one cannot add something by coming up with clever theology or philosophy. Revelation and philosophical arguments are qualitatively different.

Such a qualitative difference becomes poignantly clear if we take a case, as Kierkegaard does, where the alternative argument is not only noble, but also points in a different direction as the religious reason. Following God's order to sacrifice Isaac, and Abraham's duty to his son do not only not add to one another (being qualitatively different), but they require completely opposite actions. As soon as Abraham would begin to argue why he should follow God's command rather than his duty to his son, he annihilates the qualitative difference, given that he would start to weigh the two against one another as if they were arguments within one sphere. Here Kierkegaard ([1844] [1846] 1994:47) says: 'This paradox cannot be mediated; for as soon as he begins to do this he has to admit that he was in temptation.' Seen from the ethical perspective, Kant is right and Abraham should resist the temptation to sacrifice Isaac. As Kierkegaard ([1844] [1846] 1994:22 - my emphasis) states: 'The ethical expression for what Abraham did is, that he would murder Isaac; the religious expression is, that he would sacrifice Isaac.' These two are irreconcilable, as they belong to qualitatively different 
spheres. For people who remain in the ethical sphere, the ethical is the divine (cf. Kierkegaard [1844] [1846] 1994:51) and they can explain why one makes the choices that one makes. If, apart from following the universal ethical laws, a religious sphere exists, then the religious person standing in a 'private relationship with the deity' (Kierkegaard [1844] [1846] 1994:51) follows God in a way that is in an absolute sense beyond explanations. Kierkegaard's argument (cf. [1844] [1846] 1994:70) is that either faith in this way exists, or it does not exist at all, but is just another word for the ethical. In the ethical sphere one can argue, in the religious sphere one cannot, one can only believe in fear and trembling.

Religious judgements, being qualitatively different from ethical ones, are basically unargued. From the religious perspective, as an absolute perspective, whatever ethical reasons and arguments one may come up with is in the end irrelevant, if we allow Abraham to be the father of faith when he disregarded even such a strong ethical duty as the one to care for his son. If we transfer this again to the example of loving the girl, we see something similar if we imagine the noble alternative reason, in this case to point in an opposite direction as well. What if all the ethical reasons such as 'for sake of the children' point to someone else than the one someone claims to love? If it were true love, whatever reasons and arguments one may come up with is in the end irrelevant. As it is dangerous to say why you love someone, and Michel de Montaigne ([1580] 1958:139) famously described the concept of genuine friendship by stating that his friendship is not because of something but ' $[b]$ ecause it was he, and because it was I'. Being qualitatively different, love is basically unargued and suspends all arguments.

This also implies that one can never be sure that it really is love, however, and not, for example, lust. Not even the person concerned himself can know this, one can only believe in fear and trembling. As Kierkegaard ([1844] [1846] 1994:29) says about those 'who carry the jewel of faith': they 'are likely to be delusive, because their outward appearance bears a striking resemblance to that which both the infinite resignation and faith profoundly despise ... to Philistinism'. One cannot tell the difference between a believer or lover and a narrow-minded, materialistic, lustful Philistine.

If we now apply this to the debate on eco-theology, we can understand Jenson's plea to unarguedly dismiss all arguments for ecology. Looking for a parallel example to the one of Abraham, we might take the heating of large old churches for ever smaller congregations in Europe, or the electricity spent at crusades in Africa, as cases where ecological arguments would point towards the opposite direction as faith arguments. If, from a faith point of view these church services and crusades are necessary, one does not even need to engage in a discussion with the ecological arguments. Transversally ecologists must be able to see that the qualitative difference between faith and ecology makes such an unargued decision possibly justified. As Confucius ([890] 2007:xvii) in a slightly different context said when the king complained about the many sheep needed for sacrifices: 'You care for the sheep, I care for the ritual'. Even the argument that cares for ecology is part of our duty towards our children is in an absolute sense irrelevant given the qualitative difference between faith and ethical concerns. From an outsiders' perspective, the critics of eco-theology seem to be barbarians, and they cannot defend themselves against this charge without giving up the qualitatively different position of faith; they themselves can only believe with fear and trembling and never be sure that they are believers and not barbarians. This would also explain the previously mentioned suggestion that the concern for ecology is readily ascribed to a process and civilisation. After one transversally suspends judgement with respect to civilisation, the Kierkegaardian interpretation of the opponents to eco-theology explains how being 'uncivilised' may not be a shortcoming, but rather essential to their perspective.

Just like we cannot prove that Abraham was a friend of God instead of a murderer, just like we cannot prove that someone pursues a relationship out of love rather than lust, so we cannot prove that Jenson cum suis faithfully judge against eco-theology, and are not barbarians who chose to ignore relevant truths. In all of these cases, however, we may prove the opposite. If the opponents of eco-theology want to have a chance at rightfully claiming a qualitatively different stance rendering ecology in an absolute sense irrelevant, then they at least need to fulfil certain criteria. ${ }^{4}$ In the last section I will discuss some of these.

\section{Rules for suspension}

To qualify for a qualitative difference and its accompanying teleological suspension of the ethical including the ecological, someone criticising eco-theology needs to fulfil at least the following three criteria.

Firstly, one needs to understand and apply the concepts of a qualitative difference and teleological suspension of the ethical oneself. In The book on Adler Kierkegaard criticises Adler who claimed to have had a revelation, something qualitatively different, but in his acts betrayed that kind of difference. He did not show 'veneration for the dogmatic, qualitative concept of "a revelation"' (Kierkegaard [1844] [1846] 1994:257) by giving philosophical and theological arguments for statements that he claimed that Christ himself had dictated him. If it were truly a revelation, it would be blasphemy to give reasons for it; he should have said: 'We have Christ's word for it' (Kierkegaard [1844] [1846] 1994:210, n. 2). Adler uses 'the Christian language of concepts as a careless conversational language' (Kierkegaard [1844] [1846] 1994:254), and thereby he shows he does not understand the qualitatively different nature of Christian concepts such as 'revelation'.

Previously, we have used Jenson's statement that an unargued judgement against eco-theology is required as indication that the critique of eco-theology may be founded on qualitative differences. Jenson himself, however, does not always adhere to this line of thinking. Instead of in a transversal space acknowledging differences between faith

4.For a similar approach, see Kroesbergen (2013). 
and cosmology Jenson (2000) wants to:

$[V]$ enture a very drastic reversal of critiques. Who, after all, has decreed that the narrative spun by current cosmology is the encompassing story of reality, within which room must be found, or not found, for other narratives? (p. 338)

Instead of recognising the qualitative differences between faith and science, he (Jenson 1999) wants to turn the tables:

[T] he stories told by, for example, cosmological physics or evolutionary narrative [...] are not other stories than the story of salvation, or even its fixed presuppositions, but rather are each merely one or another abstracted aspect of it. (p. 45$)^{5}$

If Jenson wants to have a chance at justifiably claiming a qualitatively different stance rendering ecology in an absolute sense irrelevant, then he should not attempt to precede or overshadow science, but transversally acknowledge the qualitative differences between faith and science. As Buitendag (2009) states, arguing for transversal spaces: 'The difference between revelation (faith) and nature (reason) lies not in which precedes, or overshadows, the other, but rather whether they are, in fact, two distinct aspects.' In Heidegger's terms (cf. 1963:7-68) science investigates the Welt, and theology contemplates the Erde behind, beyond and through this practical, rational world around us. Buitendag (2009) regards science and theology as complementary in the human quest for understanding reality. Epistemologically it is true that the natural world is the occasion for theology, just like the physical Isaac is the occasion for Abraham's trial; however, it would be strange to call biological data regarding Isaac complementary to Abraham's religious understanding of what he was called to do. Unlike Buitendag's conclusion (2009) that 'both the Enlightenment and Liberalism had such a profound influence on theology that [...] we can no longer sharply distinguish between revelation and nature', here it is argued that precisely within the transversal space we may recognise sharp qualitative differences between revelation and science.

Secondly, if those who oppose eco-theology claim the right to do so unarguedly, based on a teleological suspension of the ethical, then they must resist taking up the position of a teacher. Kierkegaard ([1844] [1846] 1994:70) explains that ' $t]$ he true knight of faith is a witness, never a teacher', seeing as he cannot give arguments for his position. As soon as he would attempt to give reasons, he would leave the sphere of faith and enter the sphere of the ethical. That is why Abraham never explained himself to Sarah, Eleasar or Isaac:

The knight of faith is obliged to rely upon himself alone, he feels the pain of not being able to make himself intelligible to others, but he feels no vain desire to guide others. (Kierkegaard [1844] [1846] 1994:69)

If someone cannot argue that his acts are faith rather than Philistinism, love rather than lust, faithful opposition to ecology or barbarianism, then in the real sense of the word one can say nothing. As Kierkegaard ([1844] [1846] 1994:100) says of Abraham: 'Abraham is able to utter everything, but one thing he cannot say, i.e. say it in such a way that another understands it, and so he is not speaking.'

5.For a further discussion of this position, compare Kroesbergen (2012).
Now, if one stands in the qualitative different position of a teleological suspension of the ethical and attempts to be a teacher after all, one falls into the pitfall that Veldsman (2007) recognises in Barth: 'You first have to belief in Barth, then in God'. Given that you cannot speak in the real sense of the word, all you can ask people to do is to believe in you, thereby blocking people from entering into a personal relationship with God, by offering them a personal relationship with you.

Thirdly, teleological suspension of the ethical does not render the ethical superfluous or dispensable. Someone standing within the qualitatively different stance of faith knows, in Kierkegaard's words ([1844] [1846] 1994:65), 'that it is glorious to belong to the universal. He knows that it is beautiful and salutary to be the individual who translates himself into the universal'. Someone who wants to have a chance at rightfully rendering ecology irrelevant in an absolute sense, recognises that ecology is very important. About someone aspiring to do what Abraham did, Kierkegaard ([1844] [1846] 1994:23) says, 'if he does not love like Abraham, then every thought of offering Isaac would be not a trial but a base temptation'. Those who oppose eco-theology interpreted within a Kierkegaardian transversal space as we have done here; aspire to do what Abraham did. Therefore, they should love ecology with whole their heart, like Abraham loved Isaac, and only then, in fear and trembling, they may venture to say what Jenson (1999:113, n.) said: 'Recent waves of "creation spirituality" are simply apostasy to paganism. And it is such unguarded, even unargued judgement that is required of the church.'

The required attitude here is described by Wittgenstein when he states (1998):

It is the attitude of taking a certain matter seriously, but then at a certain point not taking it seriously after all, \& declaring that something else is still more serious. (p. 96e, [underlining in original])

He (1998) explains this by using the following example:

Someone may for instance say that it is a very grave matter that such \& such a person died before he could complete a certain piece of work; \& in another sense that is not what matters. At this point one uses the words 'in a deeper sense'. (p. 96e)

Someone who criticises eco-theology can only claim that 'in a deeper sense' ecology is not important, if he says that ecology in general is not important, then he is definitely not in the qualitative different stance of faith.

Therefore, the tasks for the opponents of eco-theology are to understand and apply the Kierkegaardian concepts of a qualitative difference and a teleological suspension of the ethical; to resist the temptation to assume the role of a teacher of faith; and to acknowledge the relative importance of ecology which can only be suspended afterwards in a deeper sense.

\section{Conclusion}

We have been looking for a way to resolve the deadlock in the controversy about the importance of eco-theology or creation spirituality. What is needed for those who support it and those who oppose it to re-open communication with 
one another? In this article I have proposed that instead of looking for a universal platform for communication, we could better look for a concrete transversal space between the two stances. To enter into such a space it is necessary for the proponents of eco-theology to suspend their judgements that the others are uncivilised or ignoring certain truths. Interpreting those opposed to eco-theology through the lens of the Kierkegaardian concepts of a qualitative difference and a teleological suspension of the ethical, showed that the apparent uncivilised and truth-ignoring nature of their position is not a flaw, but an essential part of the way in which they differ from eco-theologians. Finally, we saw that the opponents in turn should avoid disregarding ecology as unimportant. From a Kierkegaardian perspective, both sides should adhere to what Kierkegaard ([1846] 1968:364f.) calls: 'An absolute commitment to the absolute telos, and a relative commitment to the relative ends.' Eco-theologians should acknowledge the possibility of ecology's irrelevance in an absolute sense, and those opposed to eco-theology should acknowledge the relative importance of ecology. As a way to re-open communication within a Kierkegaardian transversal space for the controversy on eco-theology both those who support eco-theology and those who oppose it, are asked to recognise the relative importance and absolute irrelevance of ecology.

\section{Acknowledgements Competing interests}

The author declares that he has no financial or personal relationship(s) that may have inappropriately influenced him in writing this article.

\section{References}

Appiah, K.A., 2011, The honor code: How moral revolutions happen, W.W. Norton, New York.

Barth, K., 1934, Nein! Antwort an Emil Brunner, C. Kaiser, München.

Barth, K., [1922] 1968, The Epistle to the Romans, Oxford University Press, Oxford.

Buitendag, J., 2009, 'Nature as creation from an eco-hermeneutical perspective: From a "natural theology" to a "theology of nature"', HTS Teologiese Studies/ Theological Studies 65(1), 1-10. http://dx.doi.org/10.4102/hts.v65i1.272

Buitendag, J., 2013, 'Gaan na die mier, kyk na sy weë en word wys: Metafoor of paradigma?', HTS Teologiese Studies/Theological Studies 69(1), 1-9. http://dx.doi. org/10.4102/hts.v69i1.1976

Confucius, [890] 2007, The analects of Confucius: Discourses and dialogues of $K^{\prime} U n g$ Fu-Tsze compiled by his disciples, transl. H.H. Roberts, Anjeli Press, New York.
Davis, J.J., 2000, "Ecological "blind spots" in the structure and content of recent evangelical systematic theologies', Journal of the Evangelical Theological Society $43(2), 273-286$.

Deane-Drummond, C., 2008, Eco-theology, Saint Mary's Press, Winona.

Foucault, M., [1975] 1977, Discipline and punish: The birth of prison, transl. A. Sheridan, Vintage Books, New York.

Fox, M., 1991, Creation spirituality: Liberating gifts for the peoples of the world, HarperCollins, New York.

Heidegger, M., 1963, 'Der Ursprung des Kunstwerkes', in M. Heidegger, Holzwege, pp. 7-68, Viltorio Klostermann, Frankfurt am Main.

Jenson, R.W., 1999, Systematic theology: Volume 2: The works of God, Oxford University Press, Oxford.

Jenson, R.W., 2000, 'Second thoughts on theology of hope', The Evangelical Quarterly 72(4), 335-346.

Kant, I., [1793] 1960, Religion within the limits of reason alone, transl. T.M. Greene \& H.H. Hudson, Harper \& Row, New York.

Kierkegaard, S., [1846] 1968, Concluding unscientific postscript, transl. D. Swenson \& W. Lowrie, Princeton University Press, Princeton.

Kierkegaard, S., [1848] 1971, Christian discourses, transl. W. Lowrie, Princeton University Press, Princeton.

Kierkegaard, S., [1844] [1846] 1994, Fear and trembling and The book on Adler, transl. W. Lowrie, A.A. Knopf, New York.

Kierkegaard, S., [1847] 2012, Purity of heart is to will one thing, transl. D.V. Steere, Start Publishing, New York.

Kroesbergen, H., 2005, 'Scheppingsleer vs. animisme: Vergeving vragen aanbomen: Over geloofstaal', Bijdragen 66(4), 379-401. http://dx.doi.org/10.2143/ BIJ.66.4.2004376

Kroesbergen, H., 2012, De relatie tussen systematische theologie en gewone geloofstaal: Naar een alternatieve, systematische theologie, Boekencentrum Academic, Zoetermeer

Kroesbergen, H., 2013, 'The Prosperity Gospel: A way to reclaim dignity?', in H. Kroesbergen (ed.), 2013, In search of health and wealth: The Prosperity Gospel in African, pp. 78-88, Reformed perspective, CLF, Wellington.

Mackinnon, C.A., 2007, 'Of mice and men: A fragment on animal rights', in J. Donovan \& C.J. Adams (eds.), The feminist care tradition in animal ethics: A reader, pp. 316-332, Columbia University Press, New York.

Montaigne, M. de, [1580] 1958, The complete essays of Montaigne, transl. D.M. Frame, Stanford University Press, Stanford.

Rudd, A., 1993, Kierkegaard and the limits of the ethical, Oxford University Press, Oxford.

Schrag, C.O., 1992, The resources of rationality: A response to the postmodern challenge, Indiana University Press, Bloomington.

Simmons, J.A., 2009, 'Evangelical environmentalism: Oxymoron or opportunity?', Worldviews 13, 40-71. http://dx.doi.org/10.1163/156853508X394508

Springsted, E.O., 2004, 'Faith, belief and perspective: Peter Winch's philosophy of religion', Philosophical Investigations 27(4), 345-369. http://dx.doi.org/10.1111/ j.1467-9205.2004.00231.x

Sugden, C., 1993, 'Evangelicals and environment in process', Evangelical Review of Theology 17(2), 119-121.

Veldsman, D., 2007, 'Karl Barth's epistemology: A critical appraisal', HTS Teologiese Studies/Theological Studies 63(4), 1337-1345. http://dx.doi.org/10.4102/hts. v63i4.253

Wentzel van Huyssteen, J., 1999, The shaping of rationality: Toward interdisciplinarity in theology and science, Wm.B. Eerdmans, Grand Rapids.

Wentzel van Huyssteen, J., 2006, Alone in the world? Human uniqueness in science and theology: The Gifford lectures, Wm.B. Eerdmans, Grand Rapids.

White, L., 1967, 'The historical roots of our ecologic crisis', Science 155(3767), 1203 1207. http://dx.doi.org/10.1126/science.155.3767.1203

Wittgenstein, L., 1998, Culture and value, rev. edn., G.H. von Wright (ed.), Oxford University Press, Oxford.

Wittgenstein, L., 2007, Lectures and conversations on aesthetics, psychology and religious belief, C. Barrett (ed.), University of California Press, Berkeley. 